\title{
SzABó András*
}

\section{ERDÉLYIEK A WITTENBERGI MAGYAR COETUSBAN}

\author{
Kulcsszavak: wittenbergi egyetem, Melanchthon, magyar coetus, erdélyi református \\ egyház a 16. században
}

A reformáció egyetemén 1555 júniusában alakult meg Philipp Melanchthon támogatásával a magyar diáktársaság. Tagjainak többsége magyar nemzetiségú volt, 1565-1566 után a többségük a református felekezetből került ki. A coetus fennállása alatt összesen 439 tagot számlált, ők lettek a magyar református egyház vezetô rétege az első évtizedekben: nagyobb helyek lelkészei, jelentősebb iskolák tanárai, egyházi vezetôk. A többségük a Tiszántúlról, Északkelet-Magyarországról, Erdélyből és a török hódoltságból érkezett. Négy iskola bocsátotta ki nagyrészt őket: Debrecen, Várad, Sárospatak és a hódoltsági Tolna, s átlagban egy-két évet töltöttek a reformáció városában. A diáktársaságnak több funkciója is volt: tagdíjat szedett, és védte a diákok érdekeit, emellett önképzőkörként is múködött, saját, az egyetemével párhuzamos oktatási rendszert alakított ki, amelyben disputációkat rendeztek, és beszédgyakorlatokat tartottak. A coetus tagjai számos, fóként latin nyelvủ nyomtatványt is megjelentettek, a beszédek szövegén kívül leginkább latin, görög és héber alkalmi verseket, ezenbelül is a leggyakrabban a távozókat búcsúztató propempticonokat. A diáktársaság vezetője az átlagban egy esztendőre megválasztott senior volt, a szervezeti minta egyébként ugyanaz, mint a magyarországi protestáns kollégiumoknál. A coetus utolsó korszakát beárnyékolta a szászországi kryptokálvinisták és orthodox lutheránusok küzdelme, amelybe végül a magyar református diákok is belekeveredtek. 1584-től már egyébként is egyre vonzóbbá vált az újra reformátussá lett heidelbergi egyetem: egyre többen már eleve oda mentek, s fel sem keresték Wittenberget. 1592-ben rövid időre ki is tiltották a diáktársaságot a reformáció szülővárosából, de ezt még egy rövid felívelő korszak követte. Az utolsó tagok 1609-ben jöttek, a coetus anyakönyvét 1613-ban hazahozták Nagybányára, s ezzel formálisan is megszűnt a társaság. ${ }^{1}$

Ha a Wittenbergben tanult erdélyi diákokat keressük, nehéz dolgunk van, mivel nagyon kevés forrásunk maradt a református egyház 16. századi történetéről, azok ugyanis a 16-17. század fordulójának viharos eseményeiben nagyrészt elpusztultak. Az egyháztörténet rögzítette azt a szorult helyzetet, amelybe a reformátusok kerültek: alig indult meg a két nagy protestáns felekezet különválása az 1560-as évek első felében, amikor a fejedelmi támogatást is elnyert antitrinitarizmus gyors elterjedése végzetesen meggyengítette a pozíciójukat. János Zsigmond fejedelem halála és a katolikus Báthory István trónra kerülése lehetőséget adott a fellélegzésre az 1570-es években. Az új fejedelem nem tudta rögtön a katolikus egyház restaurálásával kezdeni az uralkodását, mivel ehhez hiányoztak a képzett papok és szerzetesek, így

Szabó András (1954), DSc, irodalomtörténész, egyetemi tanár, Károli Gáspár Református Egyetem, Budapest, Selye János Egyetem, Révkomárom. E-mail: szabo.andras@hungarnet.hu.

1 A magyar diáktársaság történetéról lásd Szaвó András: Coetus Ungaricus. A wittenbergi magyar diáktársaság 1555-1613. Balassi, Bp., 2017 (a továbbiakban SzAвó: Coetus Ungaricus). 
az evangélikus egyház konzervatív szárnyának erősítésével próbálkozott, s a reformátusokat támogatta az unitáriusokkal szemben. ${ }^{2}$

A lelkészi és tanári utánpótlást elsősorban a helybéli születésű s külföldi egyetemekre ment értelmiségiek erősítették. Ha a partiumi születésű diákokat nem vesszük figyelembe, akkor a kutatás jelenlegi állása szerint összesen harminchárom erdélyi coetus-tag azonosítható. Ebben legtöbbször a születési helyet jelölő névre támaszkodhatunk, amely a korabeli nem nemesi származású értelmiség jellemző sajátossága volt. Négyen közülük Erdélyen kívül futották be a pályájukat: Krakkai Demeter ${ }^{3}$ Sárospatakon tanított, Alvinczi Péter ${ }^{4}$ Váradon majd élete nagy részében Kassán lett lelkész, Dési Tamás ${ }^{5}$ szikszói prédikátorként halt meg fiatalon, Vásárhelyi Mózes ${ }^{6}$ pedig Krakkai egyik utódja volt, mint pataki tanár. Néhány módosabb nemes is volt a tagok között. Báró losonci Bánffy Ferencet ${ }^{7} 1588-1589$-ben a wittenbergi egyetem tiszteletbeli rektorának is megválasztották, s utána még Strassburgban is tanult nevelője, Baranyai Decsi János kíséretében. Ő Bánffy Farkas fejedelmi tanácsos és dobokai főispán negyedik fia volt, de későbbi életéről alig tudunk valamit. Mihályi Csáky Zsigmond ${ }^{8}$ örökölte nagy-nagybátyja, Csáky Mihály kancellár vagyonának jelentős részét, fiatalon esett el a törökök ellen vívott mezőkeresztesi csatában. Szarvaskendi Kendi Sándor a bártfai iskolában végezte középfokú tanulmányait, majd hazatérése után az Erdélyi Fejedelemség egyik vezetô politikusává vált, aki a coetust anyagilag is támogatta. Az egyesület betiltása idején a politikai befolyását is latba vetette az újraengedélyezés érdekében. Mint ellenfelét Báthory Zsigmond erdélyi fejedelem végeztette ki. Alsószopori Sulyok Imre ${ }^{10}$ hazatérése után gyors hivatali karriert csinált, s fiatal korban bekövetkezett halála előtt tanácsúr és kancellár lett.

2 ZovánYi Jenő: A magyarországi protestantizmus 1565-tôl 1600-ig. Akadémiai, Bp., 1977. 57-73.

3 Boroskrakkó, ? - Sárospatak, 1598. november vége-december eleje. 1587. augusztus 3-án lett a magyar coetus tagja, s ugyanabban a hónapban iratkozott be az egyetemre. Szabó: Coetus Ungaricus 180-181.

4 Nagyenyed, 1570 k. - Kassa, 1634. november 22. (Az ő esetében nem születési nevet látunk, mivel kisnemesi családból származott.) 1598. május 24-én lett a wittenbergi magyar coetus tagja, s 30-án iratkozott be az egyetemre. 1600-1601-ben Heidelbergben is tanult. Uo. 87-89; Heltai János: Alvinczi Péter és a heidelbergi peregrinusok. Balassi, Bp., 1994.

5 Dés, ? - Szikszó, 1575. október 10.1570. április 12-én iratkozott be a wittenbergi egyetemre, de tanult Marburgban és Heidelbergben, s meglátogatta Németalföldet, Angliát és Franciaországot is. Szaвó: Coetus Ungaricus 131.

6 Kézdivásárhely, ? - Sárospatak, 1608. július 17. előtt. 1598. április 15-én iratkozott be a wittenbergi egyetemre, s a következő napon lépett be a coetusba, de már júniusban tovább ment Heidelbergbe, ahol 1601-ig maradt. Uo. 289-290.

7 Születéséról és haláláról semmit sem tudunk. 1587. július 26-án lett a wittenbergi magyar coetus tagja, s ugyanabban a hónapban iratkozott be az egyetemre is. 1589 és 1592 között tanult még Strassburgban. Uo. 91-92.

8 ?, 1571 k. - Mezőkeresztes, 1596. október 26. 1589. június 5-én lett a magyar coetus tagja, s 21-én iratkozott be az egyetemre. Lehetséges, hogy a Partiumban született, mert szülei menyegzőjét Váradon tartották, de örökölt birtokai Erdélyben voltak. Uo. 111-112.

9 ?, ? - Kolozsvár, 1594. augusztus 30.1558. január 21-én iratkozott be a wittenbergi egyetemre. Uo. 174-175.

10 ?, ? - Gyulafehérvár, 1578. január 25. Felsőfokú tanulmányait a bécsi egyetemen kezdte 1560-ban, a wittenbergi egyetemre 1562. november 9-én iratkozott be, majd Észak-Itáliában is megfordult. Uo. 222. 
Biztosan nem Erdélyből származott, de később mégis ide került huszonkilenc coetus-tag. Nem sorolom fel őket egyenként, csak jellemző eseteket említek. Tízen a török hódoltságból jöttek: Dél-Baranyából, a magyar reformáció egyik centrumából jött például Laskai János, ${ }^{11}$ a gyulafehérvári káptalan későbbi levélkeresője és öccse, Laskai Csókás Péter, ${ }^{12}$ fogarasi és marosvásárhelyi rektor, gyulafehérvári lelkész. Tolnából származik Baranyai Decsi (Csimor) János $^{13}$ későbbi marosvásárhelyi rektor, jeles történetíró, akit már említettem, mint Bánffy Ferenc nevelőjét. Az alföldi nagy mezővárosból indult Kecskeméti Búzás Balázs, ${ }^{14}$ boroskrakkói, alvinci és szászvárosi református lelkész, az erdélyi egyházkerület püspöke. Tizenhárman partiumi származásúak, ilyen volt például Tasnádi Ruber Mihály ${ }^{15}$ bánffyhunyadi, nagyenyedi és magyarigeni lelkész, vagy Keserűi Dajka János, ${ }^{16}$ Bethlen Gábor udvari papja, mindketten erdélyi református püspökök. A Magyar Királyság területéről öten jöttek, ilyen volt Ilosvai Benedek ${ }^{17}$ tállyai evangélikus, varannói és gyulafehérvári református lelkész, a gyulafehérvári káptalan vezetője, aki a hagyomány szerint a helyi református iskola első törvénykönyvét is

11 Laskó, ? - Sellenberk, 1599. október 28.1574. szeptember 27-én iratkozott be a wittenbergi egyetemre, s ugyanaznap lett a coetus tagja is. A korábbi szakirodalom két személynek hitte. Uo. 182183.

12 Laskó,?-Gyulafehérvár, 1587. szeptember. 1577. december 10-én lett a wittenbergi magyar coetus tagja, s 1578. január 7-én iratkozott be az egyetemre. Többször járt külföldön, megfordult, Itáliában, Svájcban és Franciaországban is. Uo. 184-185; H. Hubert Gabriella: Laskai Csókás Péter peregrináció-elmélete 1581-böl = Régi és új peregrináció. Magyarok külföldön, külföldiek Magyarországon. A III. Nemzetközi Hungarológiai Kongresszuson - Szeged 1991. augusztus 12-16. - elhangzott elóadások. Szerk. BéKési Imre-Jankovics József-Kósa László-Nyerges Judit. Nemzetközi Magyar Filológiai Társaság-Scriptum Kft., Bp.-Szeged, 1993.549-555.

13 Decs, 1560 után - Marosvásárhely, 1601. május 15. 1587. július 26-án lett a wittenbergi magyar coetus tagja, s ugyanabban a hónapban iratkozott be az egyetemre is. Bánffyval együtt 1589 és 1592 között még Strassburgban tanultak. Szabó: Coetus Ungaricus 92-95; „Igniculi sapientiae”. JánosBaranyai-Decsi-Festschrift. Symposium und Ausstellung zum 400. Jahrestag des Erscheinens der Adagia von János Baranyai Decsi in der Széchényi Nationalbibliothek, 1998. Szerk. Barna Gábor-STEMLER Ágota-Voigt Vilmos. OSZK-Osiris, Bp., 2004.

14 Kecskemét,? - Szászváros, 1603?. 1588. május 21-én lett a wittenbergi magyar coetus tagja, s 25-én iratkozott be az egyetemre. Szabó: Coetus Ungaricus 172; Gudor Kund Botond: Az eltünt Gyulafehérvári Református Egyházmegye és egyházi közösségei. Inquisitoria Dioceseos Alba-Carolinensis Reformatae Relatoria (1754). Kriterion-Tortoma, Kvár-Barót, 2012. 33, 35-36; Sipos Gábor: Reformata Transylvanica. Tanulmányok az erdélyi református egyház 16-18. századi történetébez. EME, Kvár, 2012. 68-69.

15 Tasnád, ? - Magyarigen, 1618. szeptember 24. 1587. november 4-én lett a wittenbergi magyar coetus tagja, s 17-én iratkozott be az egyetemre. Szabó: Coetus Ungaricus 172; Gudor: i. m. 36-39; Sipos: i. m. 68-72.

16 Érkeserű, 1580 k. - Gyulafehérvár, 1633. május 18.1607. augusztus 15-én iratkozott be a wittenbergi egyetemre, de a következő esztendőtől már Marburgban, 1609-től Heidelbergben tanult. Szabó: Coetus Ungaricus 175-176; Heltai János: Adattár a heidelbergi egyetemen 1595-1621 között tanult magyarországi diákokról és pártfogóikról. Az Országos Széchényi Könyvtár Évkönyve 1980. Bp., 1982.292-293.

17 Ilosva, ? - Gyulafehérvár, 1586 nyara. 1558. július 7-én iratkozott be a wittenbergi egyetemre, ahol 1561. március 4-én magiszteri címet is szerzett. Szabó: Coetus Ungaricus 155-156; Uő: Ilosvai Benedek gyulafehérvári plébános = Eruditio, virtus et constantia. Tanulmányok a 70 éves Bitskey István tiszteletére. Szerk. Imre Mihály-Oláh Szabolcs-Fazakas Gergely Tamás-Száraz Orsolya. Egyetemi, Debrecen, 2011. 627-633. 
összeállította. Kassai Zsigmond Dávid ${ }^{18}$ jeles humanista író volt, a váradi, majd gyulafehérvári iskola rektora. A legmesszebbről Zalai Kápolnai András ${ }^{19}$ gyulafehérvári és szászvárosi lelkész érkezett, az ő életrajzát kivételesen jól ismerjük, ugyanis fennmaradtak naplófeljegyzései, amelyeket egy 1573-as kiadású öröknaptárba, egy ún. Eber-kalendáriumba írt. Halála után a kötetet a partiumi származású egyetemi társa, Piskolti Fabricius Mátyás ${ }^{20}$ (piskolti, küküllővári, sárdi, szászvárosi, dévai és marosvásárhelyi lelkész) örökölte, s tovább vezette a naplófeljegyzéseket. A kéziratot, amely ennek a korszaknak ritka és értékes dokumentuma, csak kivonatos publikációból ismerjük, az eredetijét a gyulafehérvári Batthyány Könyvtár őrzi. $^{21} \mathrm{Az}$ Erdélyen kívüliek beáramlása nagyobb mértékben az 1570 -es években kezdődött, ez összefügg Báthory István egyházpolitikájával, aki vissza akarta szorítani az unitáriusokat, s erre eleinte alkalmas eszköznek látta a reformátusok megerősítését. ${ }^{22}$ Ennek jellemző momentuma volt a gyulafehérvári unitáriusok elüldözése: a székesegyház és az iskola ekkor került a reformátusok kezébe. ${ }^{23}$

A diáktársaság erdélyi tagjai közül hazatérésük után hárman lettek unitáriusok, a legismertebb közülük Basilius István, ${ }^{24}$ aki az új egyház egyik vezető egyéniségévé vált, s ezért a nevét utólag ki is húzták a coetus anyakönyvéből. Ugyancsak áttért Bessenyei Jakab ${ }^{25}$ is, aki az 1580-as években konzisztóriumi tag és a háromszéki unitárius egyházkör esperese volt. A harmadik Lippai Péter ${ }^{26}$ lett, aki világi pályára lépett, és a gyulafehérvári káptalan levélkeresőjeként kereste a kenyerét. Talán szintén Erdélyben múködött később az a Kálvinnak levelet író Krasznai Ferenc, akiről csak azt tudjuk, hogy később ő is átállt az antitrinitáriusok közé. ${ }^{27}$

18 Kassa, 1556 - Nagyszeben, 1586. A wittenbergi egyetemre 1577. június 10-én iratkozott be, de még ez év őszén továbbment Heidelbergbe, majd egy esztendő múlva Tübingenbe. Szabó: Coetus Ungaricus 168-169.

19 ?, 1555 k. - Szászváros, 1588. december 23. 1578. április 17-én lett a wittenbergi magyar coetus tagja, s 26-án iratkozott be az egyetemre. Uo. 293; BARTs Gyula: Zalai Kápolnai András és Piskolti Fabricius Mátyás élete és feljegyzései. Sopron, 1929.3-4, 12-13.

20 Piskolt, 1555 k. - Marosvásárhely, 1601 vége. 1578. április 26-án iratkozott be a wittenbergi egyetemre. Szabó: Coetus Ungaricus 214; Barts: i. m. 4-11, 13-15.

21 A fontos forrás kiadásán Ösz Sándor Előd dolgozik.

22 ZováNYI: $i . m .73$.

23 Szabó András: Antitrinitáriusok, reformátusok és jezsuiták Gyulafehérvárott, 1557-1588. Erdélyi Múzeum LXXVII(2015). 1. sz. 42-50.

24 Kolozsvár, 1525 k. - ?, 1592 első fele. 1549. július 22-én iratkozott be a wittenbergi egyetemre, s 1550 második felében a jénaira; 1555 . július 22-én alapító tagja lett a wittenbergi magyar coetusnak. Szabó: Coetus Ungaricus 95; Mihály Balázs: István Basilius = Ungarländische Antitrinitarier (Tamás Arany, István Basilius, István Csázmai, Lukács Egri, Elias Gczmidele). Koerner, Baden-Baden et Bouxviller, 1990 (Biblioteca Dissidentium XII). 51-104.

25 Életéről nagyon keveset tudunk. 1558. június 15-én iratkozott be a wittenbergi egyetemre. Szaвó: Coetus Ungaricus 102.

26 Születési és halálozási dátuma nem ismert. 1568. május 22-én iratkozott be a wittenbergi egyetemre. Uo. 186; Gálfi Emőke: A gyulafehérvári hiteleshely levélkeresői (1556-1690). EME, Kvár, 2015 (Erdélyi Tudományos Füzetek 283). 37, 63-65.

27 Szabó: Coetus Ungaricus 182; Ôsz Sándor Előd: A Kálvinnak levelet író magyarról. Új adatok Krasznai Ferenc életéhez = Hittel és humorral. Tanulmánykötet a 60 éves Hörcsik Richárd születésnapjára. DRHE, Debrecen, 2015. 83-90. 
Ha a vallásváltásról beszélünk, nem hagyhatjuk ki Fodor Bálintot ${ }^{28}$ sem, aki Fodor István kolozsvári bíró fia volt. Ô kezdetben Kálmáncsehi Sánta Márton zwingliánus irányzatát követte, de 1561 után, mint a nagyszebeni magyarok prédikátora, lutheránus lett. S feltétlenül meg kell említenünk az egyetlen erdélyi szász evangélikust, aki belépett a diáktársaságba, Michael Hartmannt. ${ }^{29}$ A magyarázatot erre a kivételes lépésre talán az adja meg, hogy külföldi peregrinációja előtt Debrecenben tanult. A sok tanár és lelkész között kevesen voltak olyanok, akik világi pályára léptek, a gazdagabb nemeseken kívül ilyen volt a már említett Laskai Jánoson és Lippai Péteren kívül Kopácsi Ferenc. ${ }^{30}$ Kopácsi Bihar mezőváros beosztott lelkészeként kezdte a pályáját, de később Békés Gáspár, majd Báthory István és Kristóf szolgálatába állt, élete végén pedig a Kassán múködő Szepesi Kamara tanácsosaként dolgozott.

Ugyan nagyon sok esetben hiányoznak a biográfiai adatok, az ismert életrajzi pályák mégis kirajzolják azokat a református központokat, ahol az akadémikus (külföldi egyetemeken is járt) egyházi értelmiségiek tevékenykedtek. Ez az a korszak, amikor az unitáriusok még nyomasztó fölényben voltak, így nem meglepő, hogy erősen eltér az így kapott kép a 17. századitól. Marosvásárhelyen kívül elsősorban Dél-Erdély jelenik meg református centrumként: Alvinc, Boroskrakkó, Gyulafehérvár, Szászváros, Déva, Nagyenyed, Fogaras, Magyarigen és Küküllővár. Jelentős szerepet kellett játszania a gyulafehérvári iskolának is, de errôl szinte semmit sem tudunk, a tanárok listája hiányos, sem szabályzat, sem diáknévsor nincs a kezünkben. Valamennyire kirajzolódik a református egyházat és a peregrináló diákokat támogató főnemesi pártfogók névsora is: Bocskai István és családja, ${ }^{31}$ a losonci Bánffyak (Bánffy Ferenc coetus-tag), a mihályi Csákyak ${ }^{32}$ (Csáky Zsigmond coetus-tag), szarvaskendi Kendi Sándor (maga is coetus-tag), Kovacsóczy Farkas, ${ }^{33}$ Apafi Miklós (a későbbi erdélyi fejedelem, Mihály nagyapja). ${ }^{34}$ Kovacsóczy és Kendi közös levélben fordultak 1592. december 10-én Frigyes Vilmos szász helytartóhoz a coetus kitiltásának feloldása érdekében. ${ }^{35}$

28 Kolozsvár, ? - Nagyszeben?, ?. 1555. június 4-én iratkozott be a wittenbergi egyetemre, s június 24-én a coetus alapító tagja volt. Szabó: Coetus Ungaricus 142.

29 Apold, ? - Szászújfalu, 1587. 1569. április 6-án iratkozott be a wittenbergi egyetemre, s 24-én lépett be a magyar coetusba. Uo. 151; Ernst Wagner: Die Pfarrer und Lehrer der Evangelischen Kirche A. B. in Siebenbürgen. I. Band: Von der Reformation bis zum Jahre 1700. Böhlau, Köln-WeimarWien, 1998.69.

30 ?, ? - Kassa, 1598. május 13. (Kopácsi István korai reformátor fia vagy unokaöccse, tehát vagy a Partiumból, vagy a Magyar Királyságból érkezett.) 1567. március 3-án iratkozott be a wittenbergi egyetemre. 1569 és 1571 között Lipcsében is tanult. Szabó: Coetus Ungaricus 178-179.

31 Bővebben lásd Szabó András: „Téged Isten dicsérünk”. Bocskai István, Erdély és Magyarország fejedelme. Második, átdolgozott kiadás. Kálvin, Bp., 2010. 53-67.

32 Csáky Mihály kancellár élete utolsó néhány évében talán antitrinitárius lett. Vö. MoLnÁr Dávid: Csáky Mihály levelének elötörténetéhez. Keresztény Magvető 116(2010). 1. sz. 45-51.

33 Petneházi Gábor: Kovacsóczy Farkas kortörténeti feljegyzései (1563-1567). Lymbus. Magyarságtudományi Forrásközlemények (2012-2013). 57-94; SzAвó: Coetus Ungaricus 31, 76, 92, 93, 154, 169, 175.

34 Uo. 50, 186; Politika és házasság. Mennyegzöre hivogató levelek a 16. századi Erdélyböl. Kiad. HoRN Ildikó-Kreutzer Andrea-Szabó András Péter. ELTE BTK, Bp., 2005 (TDI Könyvek 2). 139 141.

35 Géza Szabó: Geschichte des ungarischen Coetus an der Universität Wittenberg 1555-1613. Akademischer, Halle (Saale), 1941. 124-125. 
A wittenbergi magyar diáktársaság tagjai közül kerültek ki a késóbbi erdélyi református püspökök: Tordai Sándor András, ${ }^{36}$ Toronyai Máté, ${ }^{37}$ Ungvári Fabricius János, Kecskeméti Búzás Balázs, Tasnádi Ruber Mihály és Keserúi Dajka János. Ugyanez a helyzet az ismert esperesek többségével is, bár itt ismét csak utalnom kell arra, hogy erről a korszakról nagyon hiányos a tudásunk. Végeredményben elmondható, hogy a wittenbergi egyetem neveltjei és a magyar coetus tagjai jelentős szerepet játszottak abban, hogy a református egyház Erdélyben túlélte az antitrinitarizmus rohamos térhódítását, a Báthoryak ellenreformációs kísérleteit, valamint a tizenöt éves háború pusztításait.

\section{TRANSYLVANIAN STUDENTS IN THE HUNGARIAN COETUS OF WITTENBERG}

\section{Keywords: University of Wittenberg, Melanchthon, Hungarian coetus, Transylvanian reformed church in the $16^{\text {th }}$ century}

The Hungarian coetus of Wittenberg was founded in June 1555 with the support of Philipp Melanchthon, and ended its activity in 1613 . The members of the community played an important role in the education of the first generations of the Hungarian Calvinists. Although our sources on the $16^{\text {th }}$ century history of the Transylvanian reformed church are scarce, it proved to be enough to identify thirty-three members originating from this region. Following their peregrinations, four of them fulfilled their carrier outside Transylvania, another four were prosperous nobles, but the majority most probably returned home and served their homeland. Twenty-nine of them came from outside Transylvania, either from the Ottoman Empire, from the Parts (Partium Regni Hungariae) that belonged to Transylvania, or from the Hungarian Kingdom which was under Habsburg supremacy, - but continued their carrier here. Three, possibly four members of the coetus became priests of the Unitarian and another one of the Lutheran church. Among other members, there was a Transylvanian Saxon student of Lutheran religion, the only exception of this kind. After their return to Transylvania, the places of their activities mark the ecclesiastical centres of the contemporary Reformed church, mainly in the southern part of the state. Many members of their group became either leaders in the Reformed church, or priests and professors of the most important places of the Principality.

36 Torda, 1536. november 30. - Déva, 1579.1554. április 13-án iratkozott be a wittenbergi egyetemre, s a coetus alapító tagja lett 1555. június 24-én. Szabó: Coetus Ungaricus 274-275; Ôsz Sándor Előd: Tordai Sándor András, az erdélyi reformátusok harmadik püspöke. Református Szemle 97(2004). 234-245; Uő: Tordai Sándor András erdélyi református püspök két könyvéról = In via eruditionis. Tanulmányok a 70 éves Imre Mihály tiszteletére. Szerk. Bitskey István-FazaKas Gergely TamásLuffy Katalin-Száraz Orsolya. Egyetemi, Debrecen, 2016. 315-324.

37 Temesvár?, ? - Retteg, 1599. május 5. 1572. január 12-én iratkozott be a wittenbergi egyetemre, ahol a magyar coetus huszonötödik seniorának is megválasztották. SzABó: Coetus Ungaricus 276. 


\section{STUDENT,I TRANSILVǍNENI ÎN UNIUNEA STUDENT,ILOR MAGHIARI (COETUS UNGARICUS) DIN WITTENBERG}

\section{Cuvinte-cheie: Universitatea din Wittenberg, Melanchthon, Coetus Ungaricus, biserica reformată din Transilvania în secolul al XVI-lea}

Uniunea Studenților Maghiari din Wittenberg a fost înființat în iunie $1555 \mathrm{cu}$ aportul lui Philipp Melanchthon, și și-a încheiat definitiv activitatea în 1613. Uniunea a avut un rol hotărâtor în formarea intelectuală a primelor generații de reformați. $\mathrm{Cu}$ toate că izvoarele legate de istoria bisericii reformate din Transilvania din secolul al XVI-lea nu abundă, am reușit să identificăm 33 de membri ai uniunii originari din Transilvania. Patru dintre ei și-au făcut renume în afara țării, iar alți patru au provenit din rândul nobilimii mai înstărite. 29 au fost originari din afara Transilvaniei, - adică din teritoriile ocupate de turci, din Partium și din acele părți ale Regatului Maghiar medieval, care au fost sub dominație Habsburgică, - dar și-au desfășurat activitatea pe aceste meleaguri. După reîntoarcere trei, posibil chiar patru membri ai uniunii au devenit predicatori unitarieni, iar unul a devenit adeptul religiei evanghelice-luterane. În mod excepțional un student luteran al națiunii săsești din Transilvania a devenit la rândul lui membru al uniunii. Întorcându-se acasă, acele locuri unde și-au desfășurat activitățile au devenit cele mai însemnate centre ale bisericii reformate din Transilvania vremii, aflându-se de regulă în părțile sudice ale țării. Totodată mai mulți dintre membrii uniunii au devenit liderii bisericii reformate sau predicatorii și profesorii celor mai importante localități din țară. 